\title{
Identification of four SNPs and association analysis with meat quality traits in the porcine Pitx $2 c$ gene
}

\author{
WU WangJun ${ }^{1}$, ZUO Bo ${ }^{1}$, REN ZhuQing ${ }^{1}$, HAPSARI A.A.R ${ }^{2}$, LEI MingGang ${ }^{1}$, \\ XU DeQuan ${ }^{1}$, LI FengE $^{1} \&$ XIONG YuanZhu ${ }^{1 *}$ \\ ${ }^{1}$ Key Laboratory of Swine Genetics and Breeding, Ministry of Agriculture and Key Laboratory of Agriculture Animal Genetics, Breeding and \\ Reproduction, Ministry of Education, College of Animal Science, Huazhong Agricultural University, Wuhan 430070, China; \\ ${ }^{2}$ Faculty of Animal Agriculture, Diponegoro University, Tembalang Campus-Semarang 50275, Indonesia
}

Received October 28, 2010; accepted February 28, 2011

\begin{abstract}
The association of the porcine Pitx2c gene with meat quality traits was investigated in the present study. A total of eight single nucleotide polymorphisms (SNPs) were found. Allele frequencies of four SNPs were further detected in four commercial breeds and eight Chinese indigenous breeds. Single SNP and meat quality associations were analyzed in a Yorkshire $\times$ Meishan $\mathrm{F}_{2}$ population. The SNPs c. $474 \mathrm{C}>\mathrm{T}(P<0.01)$ and c.636C $>\mathrm{T}(P<0.05)$ showed a significant association with meat color (MCV1). The SNPs c. $* 37 \mathrm{G}>\mathrm{A}$ and $\mathrm{c} . * 47 \mathrm{G}>\mathrm{A}$ were significantly associated with drip loss rate (DLR), water holding capacity (WHC) and meat color value (MCV1) consistently $(P<0.05)$. Linkage disequilibrium (LD) analysis revealed that the adjacent SNPs were in LD. Two major haplotypes were identified, and association analysis between haplotype combinations and meat quality indicated that the presence of two copies of haplotype 1 -CCGG- may improve meat quality.
\end{abstract}

association, haplotype, Pitx2c, meat quality, pig

Citation: Wu W J, Zuo B, Ren Z Q, et al. Identification of four SNPs in the porcine Pitx2c gene and association with meat quality traits. Sci China Life Sci, 2011, 54: 426-433, doi: 10.1007/s11427-011-4167-9

Meat is an important requirement for human nutrition and contains essential protein components. Improvement in the quality of meat would likely increase consumer acceptance and perception of meat, and therefore directly impact meat animal breeding programs. In the past, pig breeding research has focused on growth rate, food conversion ratio and lean meat content [1]. However, selection for these traits may lead to dramatic consequences for behavioral, physiological and immunological traits [2], will increase the incidence of pale, soft and exudative meat (PSE) and reduce the intramuscular fat content $[3,4]$. Thus, in recent years, meat quality traits have received closer attention in pig breeding programs.

Conventional selection methods have been very effective

*Corresponding author (email: xiongyz@public.wh.hb.cn) in improving growth rate, food conversion ratio and lean meat content, but very little improvement has been made to meat quality traits. With the development of modern molecular biology and genomic technology, marker-assisted selection (MAS) is one technique that has been considered by numerous breeders. MAS can be used not only to select some quantitative traits by traditional means such as using melanocortin receptor 4 (MC4R) to increase marbling, but also to select sex-limited, age-limited and meat quality traits which cannot be selected by traditional means. Moreover, MAS can help pig breeders to remove the harmful major mutations [5-9], and increase the accuracy of selection and selection response in a population. The identification of major genes, or tightly linked markers, would provide an important base for MAS application. However, until now just a few major genes have been successfully identified 
such as $R Y R 1, R N$ and $I G F 2$ genes [6,10,11]. Single nucleotide polymorphisms (SNPs), the most frequent form of DNA variations in mammals, are well suited for MAS of economic traits in meat animal breeding. So far, a large number of SNPs have been identified to be associated with economic traits in various pig populations [12-16], but the valuable SNP molecular markers are limited. Therefore, more major genes and SNP molecular markers still need to be identified. There are three approaches that can be used to identify major genes [17]: The first method is to observe whether the 'major genes' are segregating in the population; the second is the 'genomic scan' method; and the third is the candidate gene approach, which is more straightforward and cheaper when compared with the other two approaches [18-20].

Pitx2 is a paired-related homeobox gene that was originally identified as one of the genes responsible for human Rieger syndrome, an autosomal dominant condition [21]. Studies on Pitx2-deficient mice show disturbances in the development of multiple organs including body-wall, skin, ocular, right pulmonary isomerism, heart, pituitary gland and tooth organogenesis problems [22,23]. It also plays an important role in cell type-specific control of proliferation by combining with general growth factor signal pathways [24], promoting muscle cell proliferation and arresting muscle cell differentiation [25]. In addition, other reports have showed that Pitx2 has a close relationship with muscle development [26-31]. Recently, the full length cDNA and genomic sequence of porcine Pitx $2 c$ was isolated and characterized in our laboratory (GenBank accession No. HM030975), and the Pitx2c gene was assigned to porcine chromosome 8 in the area of quantitative trait loci for meat quality traits by comparative mapping between pigs and humans. Moreover, tissue distributions showed that the porcine Pitx $2 c$ gene was highly expressed in skeletal muscle (data not shown).

This information has led us to choose porcine Pitx $2 c$ as a candidate gene affecting skeletal muscle growth and meat quality traits. Our main objective is to search the SNPs in the porcine Pitx $2 c$ gene and to examine the associations of its polymorphisms with meat quality traits.

\section{Materials and methods}

\subsection{Animals}

Two $F_{2}$ populations derived from the intercross of Large White and Meishan pigs that included 334 individual pigs were used for the association study. The pigs were from the Jingpin Pig Station of Huazhong Agricultural University (Wuhan, China). All animals were fed twice daily with diets formulated according to their age under a standardized feeding regimen and had free access to water. The $\mathrm{F}_{2}$ pigs were slaughtered following a common protocol [32]. The detailed traits of animals and their measurements have been described by Yang et al. [33]. Meanwhile, 12 pig breeds containing four Western breeds (100 Yorkshire, 37 Landrace, 28 Pietrain and 27 Duroc pigs) and eight Chinese indigenous breeds (50 Meishan, 25 Qingping, 18 Tongcheng, 19 Erhualian, 19 Jianli, 7 Hezuo, 19 Wannan and 12 Yangxin pigs) were used to assay the allele frequency.

\subsection{Identification of SNPs in the porcine Pitx2c gene}

In an effort to discover the SNPs in the porcine Pitx $2 c$ gene, two-pair primers (Pitx2c-4F and Pitx2c-4R; Pitx2c-7F and Pitx2c-7R; Table 1) were designed to scan the SNPs existing in the whole coding region using the cDNA from Yorkshire and Meishan pigs. Another pair of primers (Pitx2c-6F and Pitx2c-6R; Table 1) was used to amplify intron 1 of the porcine Pitx $2 c$ gene using the DNA from Yorkshire and Meishan pigs. PCR was performed in a GeneAmp PCR system 9600 (Perkin Elmer, Foster City, CA, USA) using 1.25 U LA Taq polymerase (Takara, Japan), 1×LA PCR buffer II $\left(\mathrm{Mg}^{2+}\right.$ Plus $), 0.2 \mu \mathrm{mol} \mathrm{L}{ }^{-1}$ of each dNTP, $0.2 \mu \mathrm{mol} \mathrm{L^{-1 }}$

Table 1 Information of primers used in the study

\begin{tabular}{|c|c|c|c|c|c|}
\hline Gene name & Primer name & Primer sequence $\left(5^{\prime}-3^{\prime}\right)$ & Binding region & Product size & Annealing temperature \\
\hline \multicolumn{6}{|c|}{ SNP detection primers } \\
\hline \multirow{6}{*}{ Pitx2c } & Pitx2c-7F & CTGGGTGCTGGGAACTGA & 5'-UTR & \multirow{2}{*}{854 bp } & \multirow{2}{*}{$58.5^{\circ} \mathrm{C}$} \\
\hline & Pitx2c-7R & GCTGGCTGGTGAAGTGAGT & Exon 2 & & \\
\hline & Pitx2c-4F & AGCGGACTCACTTCACCAG & Exon 2 & \multirow{2}{*}{787 bp } & \multirow{2}{*}{$60.5^{\circ} \mathrm{C}$} \\
\hline & Pitx2c-4R & GAGTGCCCACGACCTTCTA & 3'-UTR & & \\
\hline & Pitx2c-6F & CTTTGCCCACTCTTGTTTC & Exon 1 & \multirow{2}{*}{$1428 \mathrm{bp}$} & \multirow{2}{*}{$57.3^{\circ} \mathrm{C}$} \\
\hline & Pitx2c-6R & TCTTCTTGGACGGGTCTTCA & Exon 2 & & \\
\hline \multicolumn{6}{|c|}{ Genotyping primers } \\
\hline \multirow{7}{*}{ Pitx $2 c$} & PE1-1F & CAAGAATCGCCGGGCCAAAT & Exon 2 & \multirow{2}{*}{296 bp } & \multirow{2}{*}{$57.1^{\circ} \mathrm{C}$} \\
\hline & PE1-1R & TCACCGCTGAGGGCACCAT & Exon 2 & & \\
\hline & PE1-2F & CGCAGTTCAACGGGCTTAT & Exon 2 & \multirow{2}{*}{$407 \mathrm{bp}$} & \multirow{2}{*}{$57.4^{\circ} \mathrm{C}$} \\
\hline & PE1-2R & GCTGGAGTGCTGCTTTGCT & Exon 2 & & \\
\hline & $\mathrm{F} 1$ & GTGTGAGCTGCGCCCACT & 3'-UTR & \multirow{2}{*}{$105 \mathrm{bp}$} & \multirow{2}{*}{$55^{\circ} \mathrm{C}$} \\
\hline & $\mathrm{R} 1$ & TCTTGAGTGCCCACGACCT & 3'-UTR & & \\
\hline & S1 & GGGATCCTAGGACCGTGC & 3'-UTR & - & $28^{\circ} \mathrm{C}$ \\
\hline
\end{tabular}


of each primer, and $0.5 \mu \mathrm{L}$ cDNA or $1 \mu \mathrm{L}$ genomic DNA in $25 \mu \mathrm{L}$ reactions. The temperature profile was as follows: 4 min for an initial denaturation at $94^{\circ} \mathrm{C}$, and then 30 cycles of denaturation at $94^{\circ} \mathrm{C}$ for $30 \mathrm{~s}$, annealing at optimal temperature (Table 1) for $30 \mathrm{~s}$ and extension at $72{ }^{\circ} \mathrm{C}$ for $1 \mathrm{~min}$. The obtained PCR products were separated by $2.0 \%$ agarose gel electrophoresis, and purified using a Gel Extraction Kit (Sangon, Shanghai, China). The purified products were ligated into the pMD18-T vector (Takara, Japan), and transformed into Escherichia coli $\mathrm{DH} 5 \alpha$. At least three independent clones were sequenced from both forward and reverse directions by the Beijing Genomics Institute. Potential SNPs were identified by comparison of the obtained sequences from two pig breeds including Yorkshire and Meishan using DNASTAR software.

\subsection{Genotyping protocols}

The polymorphism sites c. $474 \mathrm{C}>\mathrm{T}$ and c.636C $>\mathrm{T}$ which related to the position of the translation start codon, c. $37^{*} \mathrm{G}>\mathrm{A}$ and c. $47^{*} \mathrm{G}>\mathrm{A}$, which related to the position of the stop codon (positions based on GenBank accession No. HM030975) were further typed in different pig breeds and two YorkshirexMeishan $\mathrm{F}_{2}$ reference family using PCRRFLP and pyrosequencing protocols. A Bpull02 I and Hind II PCR-RFLP assay was conducted to genotype the SNPs c. $474 \mathrm{C}>\mathrm{T}$ and c.636C $>\mathrm{T}$ polymorphisms, respectively. Primer pairs PE1-1F/R and PE1-2F/R (Table 1) were redesigned to detect c. $474 \mathrm{C}>\mathrm{T}$ and c.636C $>\mathrm{T}$ polymorphisms, respectively. The PCR reactions were carried out in a $25 \mu \mathrm{L}$ volume using $1 \mathrm{U}$ polymerase (Fermentas), $1 \times \mathrm{PCR}$ buffer, $0.2 \mu \mathrm{mol} \mathrm{L}{ }^{-1}$ of each dNTP, $0.2 \mu \mathrm{mol} \mathrm{L}{ }^{-1}$ of each primer, 2 mmol L ${ }^{-1} \mathrm{MgCl}_{2}$ and $1 \mu \mathrm{L}$ genomic DNA. The thermal profile comprised a denaturation step at $94^{\circ} \mathrm{C}$ for $4 \mathrm{~min}, 34$ cycles of $94^{\circ} \mathrm{C}$ for $40 \mathrm{~s}$, optimal annealing temperatures (Table 1) for $40 \mathrm{~s}$ and $72^{\circ} \mathrm{C}$ for $45 \mathrm{~s}$, and a final extension step of $72^{\circ} \mathrm{C}$ for $10 \mathrm{~min}$. The products were digested with a corresponding enzyme at $37^{\circ} \mathrm{C}$ for $6 \mathrm{~h}$ and the digested products were separated by electrophoresis on $2.5 \%$ agarose gels.

A pyrosequencing protocol was employed to genotype the c. $37 * \mathrm{G}>\mathrm{A}$ and c. $47 * \mathrm{G}>\mathrm{A}$ polymorphic sites, both located at $3^{\prime}$ UTR. Pyrosequencing amplification and sequencing primers were designed by Assay Design Software in Pyrosequencing ${ }^{\mathrm{TM}}$ Systems (Biotage). The R1 primer was biotin labeled and purified by HPLC, whereas other primers were unlabeled and purified using routine PAGE. A 105 bp fragment was amplified using primers F1 and R1 (Table 1). Polymerase chain reactions were performed in a volume of

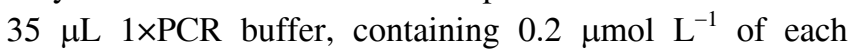
dNTP, 2 mmol L ${ }^{-1} \mathrm{MgCl}_{2}, 5$ pmol of each primer, and $1 \mathrm{U}$ Taq polymerase (Fermentas). The PCR reaction conditions were as follows: $94^{\circ} \mathrm{C}$ for $4 \mathrm{~min}$, then 40 cycles of $94^{\circ} \mathrm{C}$ for $30 \mathrm{~s}, 55^{\circ} \mathrm{C}$ for $30 \mathrm{~s}, 72^{\circ} \mathrm{C}$ for $10 \mathrm{~s}$, and a final extension of $72^{\circ} \mathrm{C}$ for $10 \mathrm{~min}$. Subsequently, the genotyping primer $\mathrm{S} 1$ was used in the sequencing of the PCR products. The sequencing reaction was conducted in the PSQ 96MA Pyrosequencing instrument (Biotage) with the Pyro Gold Reagent Kit (Biotage) according to the manufacturer's protocols.

\subsection{Statistical analysis}

The genotype distributions of four polymorphic sites in the $F_{2}$ population were tested for Hardy-Weinberg equilibrium using the online tool chi-square test (http:www.oege.org/ software/hwe-mr-calc.shtml). The linkage disequilibrium $\left(\mathrm{LD} ; r^{2}\right)$ between four SNPs was performed with HAPLOVIEW 4.2 software [34]. Haplotypes of $F_{2}$ individuals were obtained by using an efficient computer program PHASE version 2.1 [35].

The general linear model (GLM) procedure in the SAS software package (SAS Institute, Cary, NC, USA) was used to analyze the associations between single SNPs and traits. The differences between the least square means for the porcine Pitx $2 c$ genotypes were estimated using Duncan's multiple range tests with significance at $P<0.05$. The following GLM statistical model was used:

$$
T_{i j k}=\mu+S_{i}+Y_{j}+G_{k}+b_{i j k} X_{i j k}+e_{i j k},
$$

where $T_{i j k}$ is the observed values of traits, $\mu$ is the least square mean, $S_{i}$ is the effect of the $i$ th sex ( $i=1$ for male or 0 for female), $Y_{j}$ is the effect of the $j$ th year ( $j=1$ for year 2003 or 2 for year 2004), $G_{k}$ is the effect of the $k$ th genotype ( $k=1$, 2 and 3$), b_{i j k}$ is the regression coefficient of carcass weight for the traits, and $e_{i j k}$ is the random residual. The REG procedure was used to estimate the additive and dominance effects. The additive effect was estimated as $-1,0,1$ for one homozygous genotype, heterozygote genotype and the other homozygous genotype, respectively. The dominance effect was represented as -1 for heterozygote genotype, and 1 for homozygous genotype. The association analysis between certain haplotypes and traits was conducted using the statistical model mentioned above.

\section{Results}

\subsection{Genome SNP scanning of the porcine Pitx $2 c$ gene}

Three pairs of primers were used to scan 2489 bp genomic sequences covering the entire coding region, partial UTR regions and intron 1 region. A total of eight SNPs were identified, including two synonymous mutations in the coding region (c.474C $>\mathrm{T}$ and c.636C $>\mathrm{T}$; positions based on GenBank accession No. HM030975), two mutations in the 3' UTR (c. $* 37 \mathrm{G}>\mathrm{A}$ and c.*47G $>\mathrm{A}$; positions based on GenBank accession No. HM030975) and four SNPs in the first intron (g.128G >C, g. $237 \mathrm{G}>\mathrm{C}$, g.451C $>\mathrm{G}$, g.512C $>\mathrm{G}$; 
positions based on GenBank accession No. HM030974).

\subsection{Allele frequency detection of the porcine Pitx $2 c$ gene in different breeds}

For the c. $474 \mathrm{C}>\mathrm{T}$ polymorphic site, primers PE1-1F and PE1-1R were used to amplify a 296 bp fragment and the amplicon was digested with endonuclease Bpu1102 I, resulting in allele C (296 bp) and allele T (247 and $49 \mathrm{bp}$ ) (Figure 1A). For the c.636C $>\mathrm{T}$ polymorphic site, primers PE1-2F and PE1-2R were used to amplify a 407 bp fragment and the amplicon was digested with endonuclease Hind II, resulting in allele T (407 bp) and allele C (135 and $272 \mathrm{bp}$ ) (Figure 1B). Pyrosequencing protocols were implemented to genotype the SNPs c.*37G $>$ A and c.*47G $>$ A present in 3' UTR. Genotypes at four polymorphic sites and allele frequencies in different breeds are shown in Table 2. At c. $474 \mathrm{C}>\mathrm{T}$ and c.636C $>\mathrm{T}$ loci, allele $\mathrm{C}$ was over-dominant in Chinese indigenous pigs. While at c.*37G $>A$ and c. $* 47 \mathrm{G}>\mathrm{A}$ loci, the $\mathrm{G}$ allele was predominant in Chinese indigenous pigs.

\subsection{Association analysis of porcine Pitx2c single SNP with meat quality traits}

Four SNPs were in Hardy-Weinberg equilibrium in the YorkshirexMeishan $\mathrm{F}_{2}$ population (Table 3 ). The results of association analysis between single SNP and meat quality traits are shown in Table 4 . The SNP c.474C $>$ T was significantly associated $(P<0.01)$ with meat color value of the longissimus dorsi (MCV1) and the SNP c.636C $>\mathrm{T}$ had significant associations with MCV1 $(P<0.05)$. Moreover, sig-
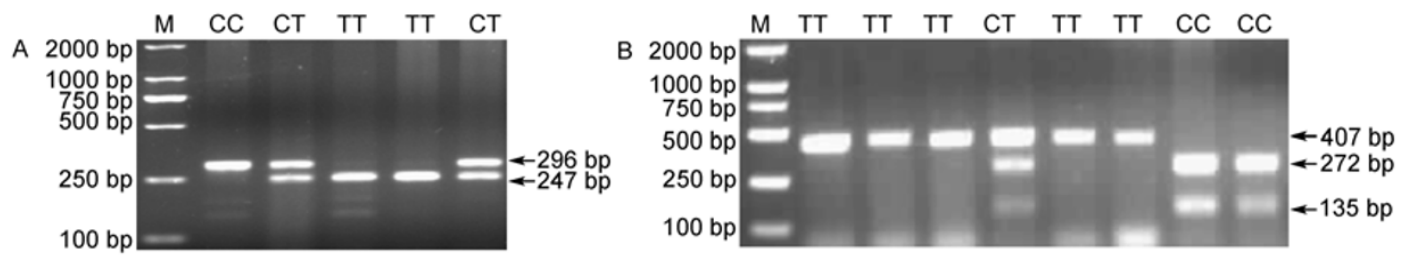

Figure 1 PCR-RFLP analysis of the porcine Pitx2c gene c.474C>T (A), c.636C > T (B) polymorphisms. The genotypes are indicated on the top of the lanes. M, DL2000

Table 2 Genotypic frequencies and allele frequencies of four polymorphisms located in the porcine Pitx2c gene ${ }^{\mathrm{a})}$

\begin{tabular}{|c|c|c|c|c|c|c|c|c|c|c|c|c|}
\hline \multirow{4}{*}{ Breed } & \multicolumn{12}{|c|}{ Polymorphisms in exon 2} \\
\hline & \multicolumn{6}{|c|}{ c. $474 \mathrm{C}>\mathrm{T}$} & \multicolumn{6}{|c|}{ c. $636 \mathrm{C}>\mathrm{T}$} \\
\hline & \multicolumn{4}{|c|}{ Genotype and frequency } & \multicolumn{2}{|c|}{ Allele frequency } & \multicolumn{4}{|c|}{ Genotype and frequency } & \multicolumn{2}{|c|}{ Allele frequency } \\
\hline & No. & TT & CT & $\mathrm{CC}$ & $\mathrm{T}$ & $\mathrm{C}$ & No. & TT & CT & $\mathrm{CC}$ & $\mathrm{T}$ & $\mathrm{C}$ \\
\hline Yorkshire & 100 & 88 & 9 & 3 & 0.945 & 0.055 & 34 & 31 & 3 & 0 & 0.977 & 0.023 \\
\hline Landrace & 37 & 36 & 1 & 0 & 0.993 & 0.007 & 32 & 32 & 0 & 0 & 1 & 0 \\
\hline Pietrain & 28 & 16 & 10 & 2 & 0.804 & 0.196 & 24 & 12 & 10 & 2 & 0.763 & 0.237 \\
\hline Qingping & 25 & 0 & 0 & 25 & 0 & 1 & 22 & 0 & 0 & 22 & 0 & 1 \\
\hline Meishan & 50 & 0 & 0 & 50 & 0 & 1 & 46 & 1 & 0 & 35 & 0.030 & 0.970 \\
\hline Tongcheng & 18 & 0 & 0 & 18 & 0 & 1 & 17 & 0 & 0 & 17 & 0 & 1 \\
\hline Erhualian & 19 & 0 & 1 & 18 & 0.014 & 0.986 & - & - & - & - & - & - \\
\hline Jianli & 19 & 0 & 0 & 19 & 0 & 1 & - & - & - & - & - & - \\
\hline Hezuo & 7 & 0 & 1 & 6 & 0.038 & 0.962 & - & - & - & - & - & - \\
\hline Wannan & 19 & 0 & 1 & 18 & 0.014 & 0.986 & - & - & - & - & - & - \\
\hline \multirow{3}{*}{ Yangxin } & \multicolumn{12}{|c|}{ Polymorphisms in $3^{\prime}$ UTR } \\
\hline & \multicolumn{6}{|c|}{ c. $* 37 \mathrm{G}>\mathrm{A}$} & \multicolumn{6}{|c|}{ c. $* 47 \mathrm{G}>\mathrm{A}$} \\
\hline & & \multicolumn{3}{|c|}{ Genotype and frequency } & \multicolumn{2}{|c|}{ Allele frequency } & & \multicolumn{3}{|c|}{ Genotype and frequency } & \multicolumn{2}{|c|}{ Allele frequency } \\
\hline Breed & No. & AA & $\mathrm{AG}$ & GG & A & $\mathrm{G}$ & No. & $\mathrm{AA}$ & $\mathrm{AG}$ & GG & $\mathrm{A}$ & $\mathrm{G}$ \\
\hline Yorkshire & 31 & 31 & 0 & 0 & 1 & 0 & 31 & 27 & 4 & 0 & 0.935 & 0.065 \\
\hline Landrace & 27 & 27 & 0 & 0 & 1 & 0 & 27 & 26 & 1 & 0 & 0.982 & 0.018 \\
\hline Pietrain & 28 & 14 & 14 & 0 & 0.750 & 0.250 & 28 & 14 & 12 & 2 & 0.714 & 0.286 \\
\hline Duroc & 27 & 7 & 18 & 2 & 0.593 & 0.407 & 27 & 7 & 15 & 5 & 0.537 & 0.463 \\
\hline Qingping & 25 & 0 & 4 & 21 & 0.080 & 0.920 & 25 & 0 & 4 & 21 & 0.080 & 0.920 \\
\hline Meishan & 28 & 1 & 4 & 23 & 0.107 & 0.893 & 28 & 1 & 4 & 23 & 0.107 & 0.893 \\
\hline
\end{tabular}

a) - represents the breeds that were not genotyped. 
Table 3 Genotype distribution of examined SNP in $\mathrm{F}_{2}$ populations

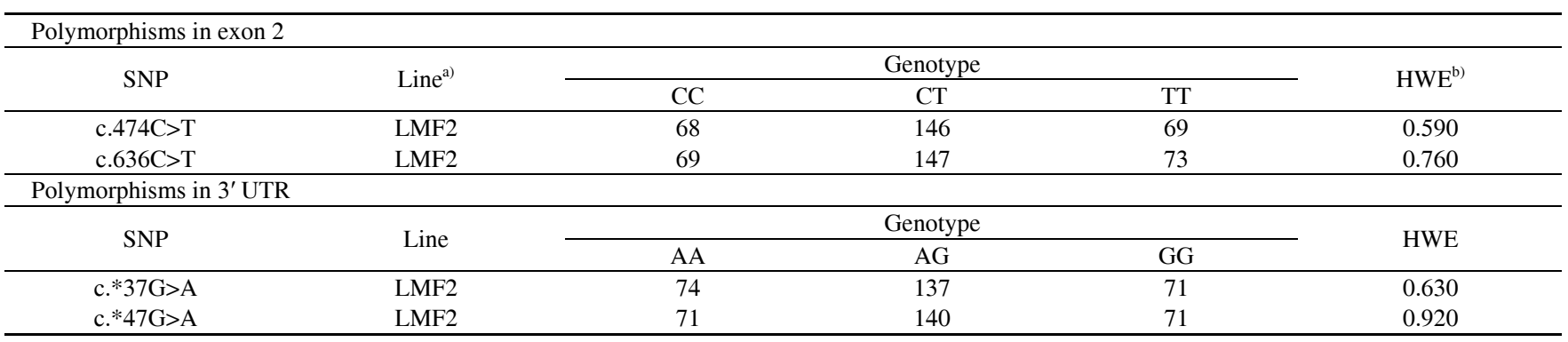

a) $\mathrm{F}_{2}$ populations derived from the intercross of Large White and Meishan pigs. b) $P$-value of a test for deviation from Hardy-Weinberg equilibrium.

Table 4 Association analysis of porcine Pitx $2 c$ polymorphisms with meat traits ${ }^{\text {a) }}$

\begin{tabular}{|c|c|c|c|c|c|c|}
\hline SNP & Traits & \multicolumn{3}{|c|}{ Genotype (mean \pm SE) } & \multicolumn{2}{|c|}{ Genetic effect (mean \pm SE) } \\
\hline \multicolumn{7}{|c|}{ Polymorphisms in exon } \\
\hline \multirow{3}{*}{ c. $474 \mathrm{C}>\mathrm{T}$} & \multirow{3}{*}{ MCV1 } & $\mathrm{CC}(n=68)$ & $\mathrm{CT}(n=146)$ & $\mathrm{TT}(n=69)$ & Additive & Dominance \\
\hline & & $18.733 \pm 0.140^{\mathrm{AB}}$ & $18.966 \pm 0.095^{\mathrm{A}}$ & $18.516 \pm 0.140^{\mathrm{B}}$ & $-0.105 \pm 0.098$ & $-0.173 \pm 0.068^{*}$ \\
\hline & & $\mathrm{CC}(n=69)$ & $\mathrm{CT}(n=147)$ & $\mathrm{TT}(n=73)$ & Additive & Dominance \\
\hline c. $636 \mathrm{C}>\mathrm{T}$ & MCV1 & $18.911 \pm 0.310^{\mathrm{ab}}$ & $19.258 \pm 0.197^{\mathrm{a}}$ & $18.575 \pm 0.273^{\mathrm{b}}$ & $-0.165 \pm 0.098$ & $-0.257 \pm 0.069^{*}$ \\
\hline \multicolumn{7}{|c|}{ Polymorphisms in $3^{\prime}$ UTR } \\
\hline \multirow[t]{2}{*}{ c. $* 37 \mathrm{G}>\mathrm{A}$} & DLR\%(LD) & $6.401 \pm 0.178^{\mathrm{ab}}$ & $6.806 \pm 0.131^{\mathrm{a}}$ & $6.338 \pm 0.181^{\mathrm{b}}$ & $-0.030 \pm 0.126$ & $-0.220 \pm 0.091^{*}$ \\
\hline & WHC\%(LD) & $91.298 \pm 0.235^{\mathrm{ab}}$ & $90.753 \pm 0.173^{\mathrm{b}}$ & $91.379 \pm 0.241^{\mathrm{a}}$ & $0.040 \pm 0.168$ & $0.295 \pm 0.121^{*}$ \\
\hline \multirow{5}{*}{ c. $* 47 \mathrm{G}>\mathrm{A}$} & MCV1(LD) & $18.645 \pm 0.133^{\mathrm{b}}$ & $19.014 \pm 0.098^{\mathrm{a}}$ & $18.682 \pm 0.136^{\mathrm{b}}$ & $0.015 \pm 0.095$ & $-0.173 \pm 0.068^{*}$ \\
\hline & & $\mathrm{AA}(n=71)$ & AG $(n=140)$ & GG $(n=71)$ & Additive & Dominance \\
\hline & DLR\%(LD) & $6.378 \pm 0.181^{\mathrm{ab}}$ & $6.807 \pm 0.129^{\mathrm{a}}$ & $6.342 \pm 0.181^{\mathrm{b}}$ & $-0.020 \pm 0.128$ & $-0.225 \pm 0.091^{*}$ \\
\hline & WHC\%(LD) & $91.326 \pm 0.240^{\mathrm{ab}}$ & $90.754 \pm 0.171^{\mathrm{b}}$ & $91.371 \pm 0.241^{\mathrm{a}}$ & $0.020 \pm 0.170$ & $0.300 \pm 0.121^{*}$ \\
\hline & MCV1(LD) & $18.614 \pm 0.135^{\mathrm{b}}$ & $19.022 \pm 0.097^{\mathrm{a}}$ & $18.681 \pm 0.136^{\mathrm{b}}$ & $0.035 \pm 0.096$ & $-0.188 \pm 0.068^{* *}$ \\
\hline
\end{tabular}

a) MCV1, Meat Color Value (m. longissimus dorsi, LD); DLR, drip loss rate of longissimus dorsi; WHC, water holding capacity of longissimus dorsi. Different superscript small letters in one row indicate significant differences at $P<0.05$; different superscript capital letters in one row indicate extremely significant differences at $P<0.01$. *, $P<0.05$; **, $P<0.01$.

nificant dominance effects were observed for MCV1 at both loci (c. 474C $>\mathrm{T}$ and c.636C $>\mathrm{T}$ ). While c. $* 37 \mathrm{G}>\mathrm{A}$ and c. $* 47 \mathrm{G}>\mathrm{A}$ polymorphisms showed significant associations with drip loss rate (DLR), water holding capacity (WHC) and meat color value $(\mathrm{MCV} 1)$ of longissimus dorsi $(P<0.05)$ and significant dominance effects were detected for all traits at both loci, especially a high significance level was observed for MCV1 at c. $* 47 \mathrm{G}>\mathrm{A}(P<0.01)$. Interestingly, the results of c. $474 \mathrm{C}>\mathrm{T}$ and c.636C $>\mathrm{T}$ were very similar to MCV1, whereas the results of $\mathrm{c} . * 37 \mathrm{G}>\mathrm{A}$ and $\mathrm{c} . * 47 \mathrm{G}>\mathrm{A}$ were very similar to all traits.

\subsection{Haplotype analysis}

Haplotype blocks and graphical representation of LD structure was generated by HAPLOVIEW 4.2 software. One haplotype block was found in the SNPs genotyped in the porcine Pit $2 c$ gene (Figure 2). As expected from the single SNP association results, SNPs c.474C $>\mathrm{T}$ and c.636C $>\mathrm{T}$ in the coding region were in $\mathrm{LD}$ with each other $\left(r^{2}=0.85\right)$, while SNPs c.*37G $>$ A and c.*47G $>$ A within $3^{\prime}$ UTR were detected in high LD $\left(r^{2}=0.95\right)$ and identified in the same amplicon. The SNP c.*37G $>$ A also displayed LD with

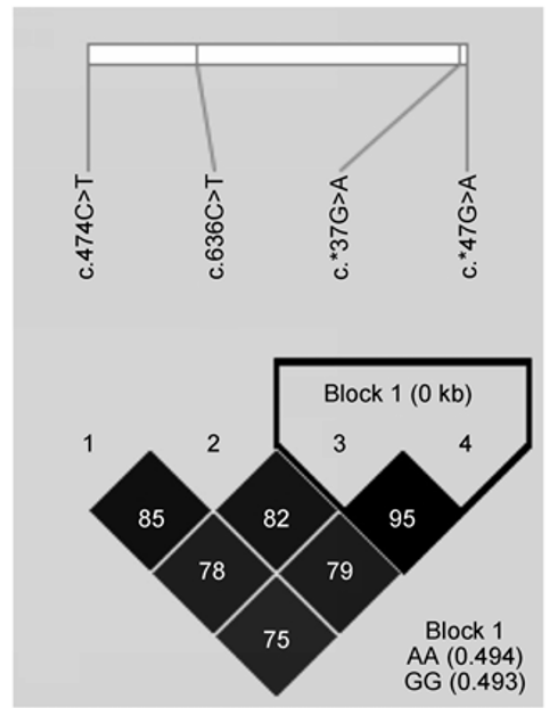

Figure 2 Linkage disequilibrium (LD) for SNPs in the porcine Pitx $2 c$ gene. Pairwise LD $\left(r^{2}\right)$ values are shown between markers. The shading represents the LD relationships with darker shading indicating higher LD. Block was generated by the default algorithm (confidence intervals) in HAPLOVIEW 4.2. One block was predicted, the block contains markers c. $* 37 \mathrm{G}>\mathrm{A}$ and $\mathrm{c} . * 47 \mathrm{G}>\mathrm{A}$. The population frequencies are listed in parentheses next to each haplotype. 
c. $636 \mathrm{C}>\mathrm{T}\left(r^{2}=0.82\right)$. Two tag SNPs c. $474 \mathrm{C}>\mathrm{T}$ and c. $* 37 \mathrm{G}>\mathrm{A}$ were predicted by HAPLOVIEW. In total, twelve haplotypes were constructed by PHASE at four polymorphic sites (Table 5), two major haplotypes accounted for $91.78 \%$ of the alleles as follows: haplotype 1, -CCGG- (45.90\%); haplotype 2, -TTAA- $(45.88 \%)$. Subsequently, the association analysis was performed between haplotype combinations and traits (Table 6). Because other haplotypes were very rare among the 12 haplotypes except for haplotypes 1 and 2 in the $F_{2}$ population (Table 5), we included only the individuals with haplotypes 1 and 2 in the association analysis. Significant differences $(P<0.05)$ were observed between haplotype combinations on MCV1 and suggestively significant $(P<0.1)$ differences were detected between haplotype combinations and DLR and WHC (Table 6).
Table 5 Haplotype and haplotype frequency of the porcine Pitx $2 c$ gene

\begin{tabular}{cccc}
\hline Index & Haplotype & $\mathrm{E}(\text { freq })^{\mathrm{a})}$ & $\mathrm{SE}^{\mathrm{b})}$ \\
\hline 1 & CCAA & 0.016894 & 0.002761 \\
2 & CCAG & 0.000146 & 0.000497 \\
3 & CCGA & 0.001812 & 0.000601 \\
4 & CCGG & 0.459048 & 0.002680 \\
5 & CTAA & 0.015679 & 0.003205 \\
6 & CTAG & 0.001953 & 0.001064 \\
7 & CTGG & 0.004605 & 0.002106 \\
8 & TCAA & 0.009468 & 0.001537 \\
9 & TCGG & 0.007721 & 0.001496 \\
10 & TTAA & 0.458881 & 0.003064 \\
11 & TTAG & 0.007223 & 0.001165 \\
12 & TTGG & 0.016549 & 0.002288 \\
\hline
\end{tabular}

a) E (freq) represents the haplotype frequency. b) SE represents the standard errors.

Table 6 Associations of porcine Pitx2c haplotype combinations

\begin{tabular}{|c|c|c|c|c|c|c|}
\hline \multirow{2}{*}{ Trait } & \multicolumn{3}{|c|}{ LSM $(\mathrm{SE})^{\mathrm{a})}$ of haplotype combination } & \multicolumn{3}{|c|}{$P$-value } \\
\hline & $11^{\mathrm{b})}$ & $12^{\mathrm{c})}$ & $22^{\mathrm{d})}$ & $11-12$ & $11-22$ & $12-22$ \\
\hline MCV1(LD) & $18.764(0.173)$ & $19.026(0.123)$ & $18.530(0.180)$ & 0.220 & 0.352 & 0.024 \\
\hline DLR\%(LD) & $6.446(0.235)$ & $6.853(0.167)$ & $6.339(0.244)$ & 0.161 & 0.753 & 0.084 \\
\hline WHC\%(LD) & $91.240(0.312)$ & $90.697(0.222)$ & $91.392(0.324)$ & 0.159 & 0.737 & 0.079 \\
\hline
\end{tabular}

a) LSM (SE) represents least squares means and their standard errors. b) 11 indicates haplotype 1, -CCGG- combined with haplotype 1 , -CCGG-. (c) 12 indicates haplotype 1, -CCGG- combined with haplotype 2, -TTAA-. (d) 22 indicates haplotype 2, -TTAA- combined with haplotype 2 , -TTAA-.

\section{Discussion}

In meat production systems, skeletal muscle tissue from slaughtered animals becomes meat for human consumption. Skeletal muscle tissue consists of many different cell types, with muscle fibers making up the majority share. Many regulatory factor genes are involved in the formation of skeletal muscle [36]. Therefore, increased knowledge about the relationship between these genes and the development and growth of skeletal muscle fibers is of utmost importance for the improvement of meat quality in pig breeding.

A multitude of studies have shown that the Pitx $2 c$ gene plays an important role in muscle development [26,27,29, 37,38]. Recently, we also found that porcine Pitx2c was expressed at its highest level in skeletal muscle (data not shown). Thus, it is reasonable for us to choose the porcine Pitx $2 c$ gene as a candidate and investigate the associations of Pitx $2 c$ polymorphisms with economic traits in Large White $\times$ Meishan $\mathrm{F}_{2}$ populations.

LD analysis indicated that the SNPs c.474C $>\mathrm{T}$ and c. $* 37 \mathrm{G}>\mathrm{A}$ were in $\mathrm{LD}$ with $\mathrm{c} .636 \mathrm{C}>\mathrm{T} \quad\left(r^{2}>0.8\right)$, while c. $* 37 \mathrm{G}>\mathrm{A}$ and $\mathrm{c} . * 47 \mathrm{G}>\mathrm{A}$ were detected in high LD $\left(r^{2}=0.95\right)$. The results suggested that these SNPs may have consistent effects on certain traits. As expected, further association analysis results showed that the four polymorphisms had significant associations with MCVl and significant dominance effects had been observed for MCV1 at four loci (Table 4). Although the SNPs c.474C $>$ T and
c.636C $>\mathrm{T}$ polymorphisms showed consistent associations with MCV1 (whether considered individually or jointly) and the individuals with the $\mathrm{C}$ allele at both loci had higher MCV1 value, there were some different effects on MCV1 between both loci. This result suggested that variations in porcine Pitx $2 c$ might be having variable effects on MCV1. The allele frequencies of the SNPs c. $474 \mathrm{C}>\mathrm{T}$ and c.636C $>\mathrm{T}$ in the Pitx $2 c$ gene showed significant difference between commercial pigs and Chinese indigenous pigs. At both loci, allele $\mathrm{C}$ was over-dominant in Chinese indigenous pigs and the allele frequencies reached 1 in several breeds (Table 2). This is consistent with the fact that the Chinese indigenous pigs have higher meat color value. In addition, we found that both of the SNPs c. $* 37 \mathrm{G}>\mathrm{A}$ and $\mathrm{c} . * 47 \mathrm{G}>\mathrm{A}$ were significantly correlated with DLR, WHC and MCV1 consistently (Table 4) and both loci c. $* 37 \mathrm{G}>\mathrm{A}$ and c.*47G $>\mathrm{A}$ displayed dominance effects for DLR and WHC, which indirectly support the result that the two loci were highly LD. The allele frequencies of c. $* 37 \mathrm{G}>\mathrm{A}$ and $\mathrm{c} . * 47 \mathrm{G}>\mathrm{A}$ also exhibited remarkable differences between commercial breeds and Chinese indigenous breeds. Chinese indigenous breeds had higher frequencies of the $\mathrm{G}$ allele at both loci. The pigs with homozygous GG had higher MCV1 and WHC, and lower DLR when compared with the AA genotype individuals, although no significance had been detected. These coincide with the fact that Chinese indigenous breeds have better meat quality than the commercial breeds. Furthermore, we found that the two loci (c.*37G>A and 
c. $* 47 \mathrm{G}>\mathrm{A})$ were significantly over-dominant in actions for MCV1, DLR and WHC. The MCV1 and DLR of AG heterozygote pigs were significantly higher than GG homozygotes while the WHC of AG heterozygote pigs was lower $(P<0.05)$. These results imply that allele $G$ at both loci c. $* 37 \mathrm{G}>\mathrm{A}$ and $\mathrm{c} . * 47 \mathrm{G}>\mathrm{A}$ was associated with good and desirable meat quality, but the heterozygotic genotype was not conducive to the improvement of meat quality. It is well known that meat quality traits such as color, drip loss and water holding capacity are correlated to meat $\mathrm{pH}$. Whereas, in our study the polymorphisms of c. $* 37 \mathrm{G}>\mathrm{A}$ and $\mathrm{c} . * 47 \mathrm{G}>\mathrm{A}$ were not found to be significantly associated with $\mathrm{pH}$, but the pigs carrying the GG had higher $\mathrm{pH}$ relative to the AA individuals (data not shown). Actually, our results were consistent with the fact that lower $\mathrm{pH}$ will be accompanied by higher DLR and lower WHC [3,39-41]. In addition, we found that the heterozygotic pigs had the lowest $\mathrm{pH}$ value, suggesting both of the loci may also display over-dominant effects on $\mathrm{pH}$. Although our results open the possibility that the polymorphisms of c. $* 37 \mathrm{G}>\mathrm{A}$ and $\mathrm{c} . * 47 \mathrm{G}>\mathrm{A}$ are associated with $\mathrm{pH}$, further work is still needed to identify the associations between the c. $* 37 \mathrm{G}>\mathrm{A}$ and $\mathrm{c} . * 47 \mathrm{G}>\mathrm{A}$ polymorphisms and $\mathrm{pH}$ in other pig populations.

From the single marker association results, it could be speculated that improving the frequencies of allele $\mathrm{C}$ at c. $474 \mathrm{C}>\mathrm{T}$ and c. $636 \mathrm{C}>\mathrm{T}$ loci and allele $\mathrm{G}$ at c. $* 37 \mathrm{G}>\mathrm{A}$ and c. $* 47 \mathrm{G}>\mathrm{A}$ loci would help to improve meat quality. To explore further, we performed the association analysis of haplotype combinations among the four SNPs, where significant associations were also observed between haplotype combinations and MCV1 $(P<0.05)$, and suggestively significant differences with DLR and WHC $(P<0.1$; Table 6). Therefore, we deduced that variations in the porcine Pitx $2 c$ gene have an effect on MCV1, DLR and WHC and the differences of the effects among the variations could be caused by the positional differences and possible interactions among these SNPs.

Here, we have identified that the polymorphisms of the porcine Pitx $2 c$ gene were significantly associated with several meat quality traits and LD was observed between the adjacent SNPs. Interestingly, the polymorphisms of the four SNPs had significant effects on MCV1. Although our results have shown the significant association between the variations of porcine Pitx $2 c$ and pork quality, further analysis to clarify the significant associations in other commercial populations is needed.

This work was supported by the National Basic Research Program of China (Grant No. 2006CB102102), National High Technology Research and Development Program (Grant No. 2006AA10Z1D6), National Natural Science Foundation of China (Grant No. 30800782) and New Teacher Research Fund for the Doctoral Program of Higher Education (Grant No. 20070504064).

1 Ollivier L, Guéblez R, Webb A J, et al. Breeding Goals for Nation- ally and Internationally Pig Breeding Organisations. 4th ed. Edingburgh: World Congress on Genetics Applied to Livestock Production, 1990

2 Rauw W M, Kinas E, Noordhuizen-Stassen E N, et al. Undesirable side effects of selection for high production efficiency in farm animals: a review. Livest Prod Sci, 1998, 56: 15-33

3 Hermesch S, Luxford B G, Graser H U. Genetic parameters for lean meat yield, meat quality, reproduction and feed efficiency traits for Australian pigs. 2. Genetic relationships between production, carcase and meat quality traits. Livest Prod Sci, 2000, 65: 249-259

4 Lonergan S M, Huff-Lonergan E, Rowe L J, et al. Selection for lean growth efficiency in Duroc pigs influences pork quality. J Anim Sci, 2001, 79: 2075-2085

5 Carr C C, Morgan J B, Berg E P, et al. Growth performance, carcass composition, quality, and enhancement treatment of fresh pork identified through deoxyribonucleic acid marker-assisted selection for the Rendement Napole gene. J Anim Sci, 2006, 84: 910-917

6 Fujii J, Otsu K, Zorzato F, et al. Identification of a mutation in porcine ryanodine receptor associated with malignant hyperthermia. Science, 1991, 253: 448-451

7 Hamilton D N, Ellis M, Miller K D, et al. The effect of the Halothane and Rendement Napole genes on carcass and meat quality characteristics of pigs. J Anim Sci, 2000, 78: 2862-2867

8 Miller K D, Ellis M, McKeith F K, et al. Frequency of the Rendement Napole RN-allele in a population of American Hampshire pigs. J Anim Sci, 2000, 78: 1811-1815

9 Moeller S J, Baas T J, Leeds T D, et al. Rendement Napole gene effects and a comparison of glycolytic potential and DNA genotyping for classification of Rendement Napole status in Hampshire-sired pigs. J Anim Sci, 2003, 81: 402-410

10 Le Roy P, Naveau J, Elsen J M, et al. Evidence for a new major gene influencing meat quality in pigs. Genet Res, 1990, 55: 33-40

11 Nezer C, Moreau L, Brouwers B, et al. An imprinted QTL with major effect on muscle mass and fat deposition maps to the IGF2 locus in pigs. Nat Genet, 1999, 21: 155-156

12 Fan B, Lkhagvadorj S, Cai W, et al. Identification of genetic markers associated with residual feed intake and meat quality traits in the pig. Meat Sci, 2010, 84: 645-650

13 Ovilo C, Fernandez A, Rodriguez M C, et al. Association of MC4R gene variants with growth, fatness, carcass composition and meat and fat quality traits in heavy pigs. Meat Sci, 2006, 73: 42-47

14 Piorkowska K, Tyra M, Rogoz M, et al. Association of the melanocortin-4 receptor (MC4R) with feed intake, growth, fatness and carcass composition in pigs raised in Poland. Meat Sci, 2010, 85: 297-301

15 Sieczkowska H, Kocwin-Podsiadla M, Zybert A, et al. The association between polymorphism of PKM2 gene and glycolytic potential and pork meat quality. Meat Sci, 2010, 84: 180-185

16 Rothschild M, Jacobsont C, Vaske D. The estrogen receptor locus is associated with a major gene influencing litter size in pigs. Proc Natl Acad Sci USA, 1996, 93: 201-205

17 te Pas M F W, Everts M E, Haagsman H P. Muscle Development of Livestock Animals: Physiology, Genetics and Meat Quality. 1st ed. Wallingford: CABI Publishing, 2004. 428

18 de Vries A G, Sosnicki A, Garnier J P, et al. The role of major genes and DNA technology in selection for meat quality in pigs. Meat Sci, 1998, 49: 245-255

19 Gerbens F, Harders F L, Groenen M A, et al. A dimorphic microsatellite in the porcine H-FABP gene at chromosome 6. Anim Genet, 1998, 29: 408

20 Short T H, Rothschild M F, Southwood O I, et al. Effect of the estrogen receptor locus on reproduction and production traits in four commercial pig lines. J Anim Sci, 1997, 75: 3138-3142

21 Semina E V, Reiter R, Leysens N J, et al. Cloning and characterization of a novel bicoid-related homeobox transcription factor gene, RIEG, involved in Rieger syndrome. Nat Genet, 1996, 14: 392-399

22 Gage P J, Suh H, Camper S A. Dosage requirement of Pitx2 for development of multiple organs. Development, 1999, 126: 4643-4651

23 Lin C R, Kioussi C, O'Connell S, et al. Pitx2 regulates lung asymmetry, cardiac positioning and pituitary and tooth morphogenesis. 
Nature, 1999, 401: 279-282

24 Kioussi C, Briata P, Baek SH, et al. Identification of a Wnt/Dvl/betaCatenin $\rightarrow$ Pitx 2 pathway mediating cell-type-specific proliferation during development. Cell, 2002, 111: 673-685

25 Martinez-Fernandez S, Hernandez-Torres F, Franco D, et al. Pitx2c overexpression promotes cell proliferation and arrests differentiation in myoblasts. Dev Dyn, 2006, 235: 2930-2939

26 Abu-Elmagd M, Francis-West P, Munsterberg A. Wnt signalling via Pitx2 regulates somite and limb myogenesis. Mech Dev, 2009, 126: S213-S213

27 Amanda E Z L, Qian M, Gage P J. Pitx2 is critical for the survival and specification of extraocular muscles. Dev Biol, 2008, 319: 536-536

28 L'Honore A, Coulon V, Marcil A, et al. Sequential expression and redundancy of Pitx2 and Pitx3 genes during muscle development. Dev Biol, 2007, 307: 421-433

29 Shih H P, Gross M K, Kioussi C. Expression pattern of the homeodomain transcription factor Pitx2 during muscle development. Gene Expr Patterns, 2007, 7: 441-451

30 Shih H P, Gross M K, Kioussi C. Cranial muscle defects of Pitx2 mutants result from specification defects in the first branchial arch. Proc Natl Acad Sci USA, 2007, 104: 5907-5912

31 Zhou Y F, Cheng G, Dieter L, et al. An altered phenotype in a conditional knockout of Pitx2 in extraocular muscle. Investig Ophthalmol Vis Sci, 2009, 50: 4531-4541

32 Xiong Y Z, Deng C Y. Principle and Method of Swine Testing. Bei- jing: Chinese Agriculture Press, 1999

33 Yang H, Xu Z Y, Lei M G, et al. Association of 3 polymorphisms in porcine troponin I genes (TNNI1 and TNNI2) with meat quality traits. J Appl Genet, 51: 51-57

34 Barrett J C, Fry B, Maller J, et al. Haploview: analysis and visualization of LD and haplotype maps. Bioinformatics, 2005, 21: 263-265

35 Stephens M, Smith N J, Donnelly P. A new statistical method for haplotype reconstruction from population data. Am J Hum Genet, 2001, 68: 978-989

36 Buckingham M, Bajard L, Chang T, et al. The formation of skeletal muscle: from somite to limb. J Anat, 2003, 202: 59-68

37 Dong F Y, Sun X X, Liu W, et al. Pitx2 promotes development of splanchnic mesoderm-derived branchiomeric muscle. Development, 2006, 133: 4891-4899

38 Evans A L, Gage P J. The essential role of Pitx2 in extraocular muscle development. Dev Biol, 2006, 295: 384-385

39 de Vries A G, van der Wal P G, Long T, et al. Genetic parameters of pork quality and production traits in Yorkshire populations. Livest Prod Sci, 1994, 40: 277-289

40 Otto G, Roehe R, Looft H, et al. Comparison of different methods for determination of drip loss and their relationships to meat quality and carcass characteristics in pigs. Meat Sci, 2004, 68: 401-409

41 Knapp P, Willam A. Genetic parameters for lean meat content and meat quality traits in different pig breeds. Livest Prod Sci, 1997, 52: 69-73

Open Access This article is distributed under the terms of the Creative Commons Attribution License which permits any use, distribution, and reproduction in any medium, provided the original author(s) and source are credited. 